\title{
Metal and Composite Intermodal Containers in Comparative Cold Tests with Wood Chips
}

\author{
Jarno Föhr ${ }^{1}$, Kalle Karttunen², Johanna Enström³ ${ }^{3}$, Tomas Johannesson ${ }^{3}$, Tapio Ranta1 \\ ${ }^{1}$ Bioenergy Technology, Lappeenranta University of Technology, Mikkeli, Finland \\ ${ }^{2}$ Department of Forest Sciences, University of Helsinki, Helsinki, Finland \\ ${ }^{3}$ Forest Energy, Forestry Research Institute of Sweden, Uppsala, Sweden \\ Email: ${ }^{\text {jarno.fohr@lut.fi }}$
}

Received 12 February 2015; accepted 2 March 2015; published 5 March 2015

Copyright (C) 2015 by authors and Scientific Research Publishing Inc.

This work is licensed under the Creative Commons Attribution International License (CC BY).

http://creativecommons.org/licenses/by/4.0/

c) (i) Open Access

\section{Abstract}

Intermodal containers have many advantages in the bulk supply chain, but idle times may cause freezing problems for containers in terminals and long-lasting deliveries, especially during the winter time in Nordic conditions. The aim of the cold tests was to study metal and composite containers' ability to tolerate wood chips freezing into the inner surface of the container. Two of the containers were normal metal containers and one was a composite container. The loaded containers were put inside the laboratory hall, the temperature of which was $-30^{\circ} \mathrm{C}$, and kept there for variable times: less than $\mathbf{2 4}$ hours. The inner surface of one of metal containers was treated with a special coolant, EC1. After the test, the chips were unloaded, and the container walls were checked to determine whether there was any material left on them. The test results indicated the advantages of composite containers having a thermally insulated structure without freezing problems. At the same time, chips were freezing badly onto the floor of both metal containers. A frozen chip layer with a thickness of approximately $50 \mathrm{~cm}-60 \mathrm{~cm}$ was stuck to the floors. As such, EC1 did not seem to prevent the freezing of the chips onto the inner surfaces. The results proved that intermodal logistics of truck and train transportation would be more suitable for composite containers than for metal containers in the winter time in Nordic conditions.

\section{Keywords}

Metal, Composite, Container, Cold Test, Wood Chips

\footnotetext{
*Corresponding author.
} 


\section{Introduction}

In 2013, the use of forest chips by heat and power plants in Finland was 8.0 million $\mathrm{m}^{3}, 16.0$ TWh, meaning an increase of $5 \%$ from the previous year [1]. The total usage of forest chips was 8.7 million $\mathrm{m}^{3}, 17.4$ TWh, including the small-scale usage of farms. The majority of forest chips were transported by trucks equipped with a solid frame, either as chips or as comminuted material [2]. In recent years, some experiments have been performed with trains and vessels. The majority of forest chips are supplied by roadside chipping directly into trucks ( 60\%), with less going via regional terminals (21\%) or directly to end-use crushing stations (18\%) [3]. According to the Finnish Ministerial working group on energy and climate policy, forest chip volumes should rapidly increase to 25 TWh until the year 2020 as a consequence of the imbalance between the locations of demand and supply, which means longer transport distances from the supply areas to the largest demand sites in Finland [4].

Regions with a high demand but low supply volumes require other logistics solutions than conventional supply methods, since transport by truck is economical only for short transport distances [5]. Long distances have made rail and waterway transportation a part of supply logistics. Forest chip supply volumes call for logistics systems including buffer terminals and transport modes suitable for longer distances. Supply costs will increase because of more handling and storage, but it is also possible to increase the availability and supply security at the same time [6]. Therefore, the need has emerged to find efficient solutions for integrating separate modes of transport. A good example of this is the development of the railway and terminal services in Sweden: container railway logistics with terminals for wood fuels have been studied and taken into operational use [7].

Intermodal containers have proven to be a promising option. The advantage of container logistics lies in the possibilities for intermodal transport and efficient terminal operations [8]. Intermodal containers have many advantages in the supply chain, but idle times may cause freezing problems for containers in terminals and longlasting deliveries, which are full of bulk material, especially during the winter time in Nordic conditions. Bulk becomes stuck onto the inner surfaces of the container as an effect of frost, and this causes unloading problems. Freezing problems typically occur when metal containers are used. According to a small-scale Swedish study, moisture content below 31\% may not lead to freezing problems concerning wood chips [9]. Freezing problems were observed when the moisture level increased to $38 \%$. A moisture level of $58 \%$ led to $100 \%$ freezing of wood chips.

The main problem of freezing starts when surface moisture freezes on the surface of solid particles: the ice acts as a powerful adhesive holding the particles together in the mass. The adhesiveness is influenced by both the particle size of the solids and the moisture content. For example coal, with as little as $4 \%$ moisture content, could cohere so strongly as to require special handling to break up the frozen mass during the winter time. Thus, it becomes difficult to unload or dump the train carriages, trucks, and other transportation vehicles. It also makes it difficult to move coal from the outdoor coal storage piles in a condition suitable for combustion or other use. The unloading of frozen material from railcars and truck vehicles is time consuming, can result in a failed dump attempt, and can often leave from $20 \%$ to $100 \%$ of material in the vehicle. Oil has often been used to freezeproof material with questionable effectiveness [10].

This study focuses on containers unloaded by truck, but there are also other unloading methods in intermodal container transport. For example, Austria-based Innofreight has the rotary unloading system. Containers are emptied by inverting with a fork-lift truck [11]. The risk of freezing exist despite the unloading method, at worst chips come out as one lump.

One solution to the freezing problems could be a new type of container (SuperCont ${ }^{\circledR}$ ) developed by Fibrocom, based on a patented channel composite structure wherein the surface laminates are bound together strongly with diagonal laminates [12]. The cross-section of the structure is reminiscent of several I beams side by side. This means a lighter, thermally-insulated, and more durable structure, and thus, a sustainable transport carrier option for container logistics [13]. The container is manufactured in "one-shot" moulding, and therefore, the walls and floor are tied together seamlessly and continuously. This way, the connections between them are very strong.

This paper concentrates on the composite and metal containers' ability to tolerate forest chips freezing into the inner surface of the container. The full intermodal containers were put inside the laboratory hall, the temperature of which was $-30^{\circ} \mathrm{C}$, and kept there for variable times less than 24 hours. The purpose of this study was to compare the reliability of metal and composite containers in demanding sub-zero conditions. The aim was to obtain accurate information on forest chip freezing behaviour in transportation containers under controlled laboratory 
conditions. According to the authors' knowledge, cold tests using containers with bulk materials have not previously been carried out so thoroughly and to such an extent.

\section{Material and Methods}

\subsection{Material}

The cold tests were carried out with three completely new transportation containers in February 2013. Two of them were normal metal containers and one was a composite container (Figure 1). The metal containers were completely identical with a volume of $37 \mathrm{~m}^{3}$ and empty weight of $2600 \mathrm{~kg}$, and the metal plate used on the walls had a thickness of $3 \mathrm{~mm}$. The volume of the composite container was $39.5 \mathrm{~m}^{3}$ and the empty weight was 1900 $\mathrm{kg}$, and the thickness of the walls was $53 \mathrm{~mm}$. The length of the containers was based on the length of the freight container: $20 \mathrm{ft}$.

The forest chips used in the study were a mixture of whole tree and lopped tree which was crushed a few days before the cold tests started. The forest chips were chosen as the delivery subject because of the popularity in Nordic countries. Especially the deliveries of wood chips are massive due to the pulp industry in Finland and Sweden.

The actual cold tests were conducted at the MTT Agrifood Research Finland test site in Vihti. The length of the laboratory hall was $14.2 \mathrm{~m}$, with a width of $5.5 \mathrm{~m}$, and height of $5.1 \mathrm{~m}$. The size of the door opening was 4.7 $\times 4.7$ meters, and thus, the hall can also accommodate larger machines. The weather conditions of the hall were adjustable, and the hall was equipped with a modern data acquisition system.

\subsection{Methods}

Six temperature sensors were installed by taping them onto the inner walls and floors of the containers before filling them with forest chips (Figure 2). The function of the sensors was to measure the temperatures at the different points on the inner surfaces of the container. An extra sensor was installed into each container to a depth of $1 \mathrm{~m}$ to measure the internal temperature of the forest chip heap. In addition, two temperature sensors measured the air temperature in the laboratory hall.

The coolant, EC1, suitable for motors, was injected onto the inside surface of one of the metal container before filling it with forest chips [14]. The dosage of the injected EC1 was 5 litres. The working range of the coolant was from $-50^{\circ} \mathrm{C}$ to $240^{\circ} \mathrm{C}$, and it was environmentally friendly and odourless. EC1 has never been tested officially with metal containers, not in Finland or in Sweden. The coolant should prevent the forest chips from freezing onto the metal surface. In that case, it would be possible to compare the treated and untreated metal container with each other. All the containers were at the mercy of the outside temperature during the period when they were not in the controlled laboratory hall. The outside temperature varied between $2^{\circ} \mathrm{C}$ and $-4^{\circ} \mathrm{C}$.

The metal containers were kept at $-30^{\circ} \mathrm{C}$ for 12 hours, and they were kept in the cold test for the same time. The composite container was similarly kept at $-30^{\circ} \mathrm{C}$ for 12 hours, but also an additional third freezing test of 24 hours was carried out at the same temperature. The roof parts of the containers were not covered with a tarpaulin during the cold tests.

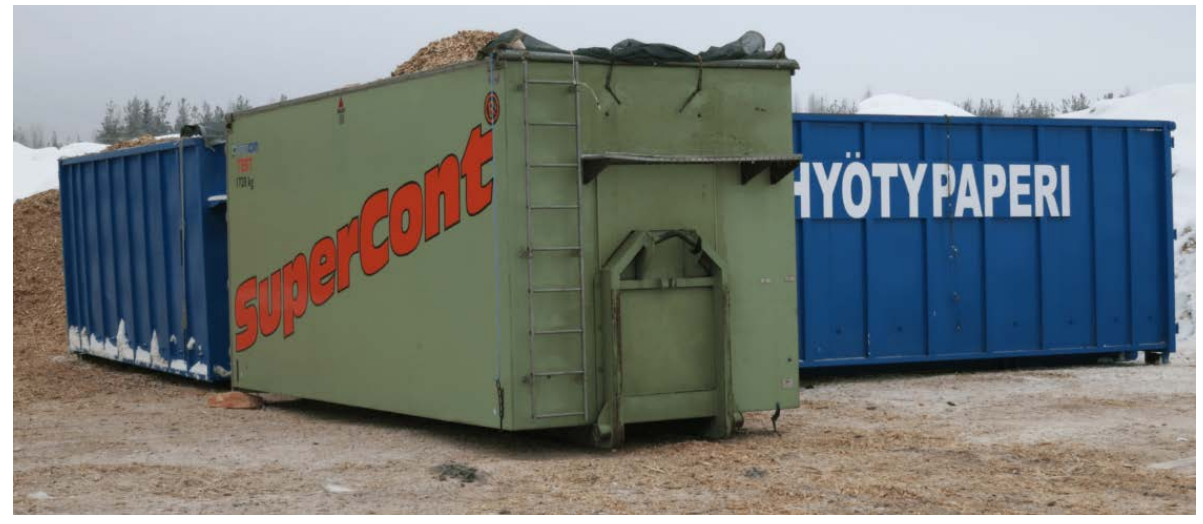

Figure 1. Metal and composite containers. 


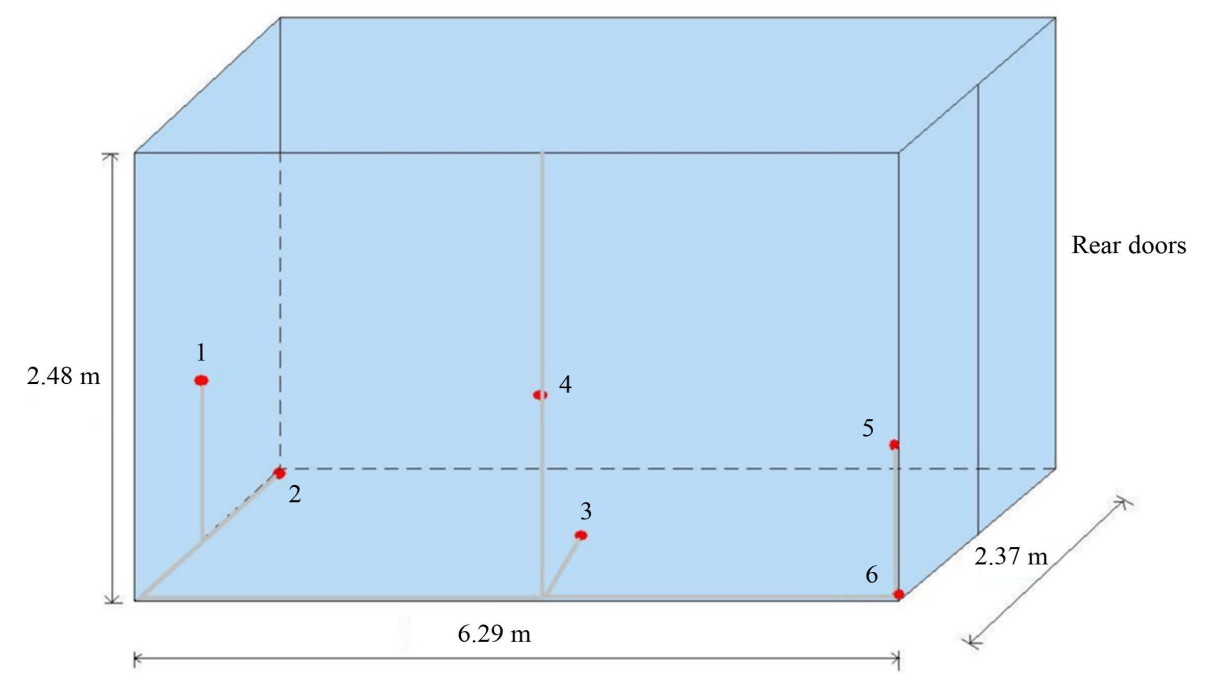

Figure 2. Location of temperature sensors within the containers.

The containers were unloaded by a truck in MTT's fields after each test. The containers were weighed before and after the unloading to find out the weight of the frozen forest chips on the inside surfaces of the containers. Two moisture samples were taken and placed in a sample bag from each container during the unloading. The samples were analysed using the oven drying method.

The laboratory gauges measured the temperature of the sensors once a minute. The collected data was extensive and it is shown in the graphs. The temperature measurements of containers' inner surfaces and air temperature are presented as means.

\section{Results}

\subsection{The 12-Hour Test with Metal Containers}

Based on the oven drying measurement, the average moisture content of forest chips was $47.0 \%$ in the first metal container and $49.1 \%$ in the second metal container. The weight of the forest chips was $11.95 \mathrm{t}\left(320 \mathrm{~kg} / \mathrm{m}^{3}\right)$ in the first metal container and $11.65 \mathrm{t}$ in the second metal container. The first metal container was treated with a coolant. Figure 3 shows the results of the temperature measurements of forest chips and inner surfaces of the metal containers during the 12-hour cold test.

Figure 3 shows that the temperature results were similar in both of the metal containers. The temperature was below zero on the inner surfaces of the containers both in the beginning and at the end of the cold test. The temperature decreased from $-2^{\circ} \mathrm{C}$ to $-25^{\circ} \mathrm{C}$ on the inner surfaces, but stayed stable at $-2^{\circ} \mathrm{C}$ at a depth of $1 \mathrm{~m}$ in the heap of forest chips. All the containers were loaded in the open air where the temperature was below zero two days before the tests began.

The forest chips were unloaded after the cold test. The outer walls of the metal containers were beaten with forge hammers. Many tipping attempts were needed to dump all the chips that could be unloaded. The chip content was frozen throughout in such a way that the chips were frozen to each other forming a $20 \mathrm{~cm}$ layer from the content surface in both of the metal containers. There was also some freezing below the entirely frozen layer, but these lower chips were not frozen to each other. Both of these metal containers were emptied for the most part, but a layer of the frozen forest chips with a thickness of approximately $50 \mathrm{~cm}-60 \mathrm{~cm}$ was stuck onto the floors and did not come out despite the tipping. Figure 4 shows the situation of one metal container before and after unloading. The situation was the same for both of the metal containers. The residual frozen forest chips weighed $2.09 \mathrm{t}$ (17\% of the total weight) in the first metal container and $1.59 \mathrm{t}$ ( $14 \%$ of the total weight) in the second metal container.

\subsection{The 12-Hour Test with the Composite Container}

Based on the oven drying measurement, the average moisture content of the forest chips was $48.7 \%$ and the 


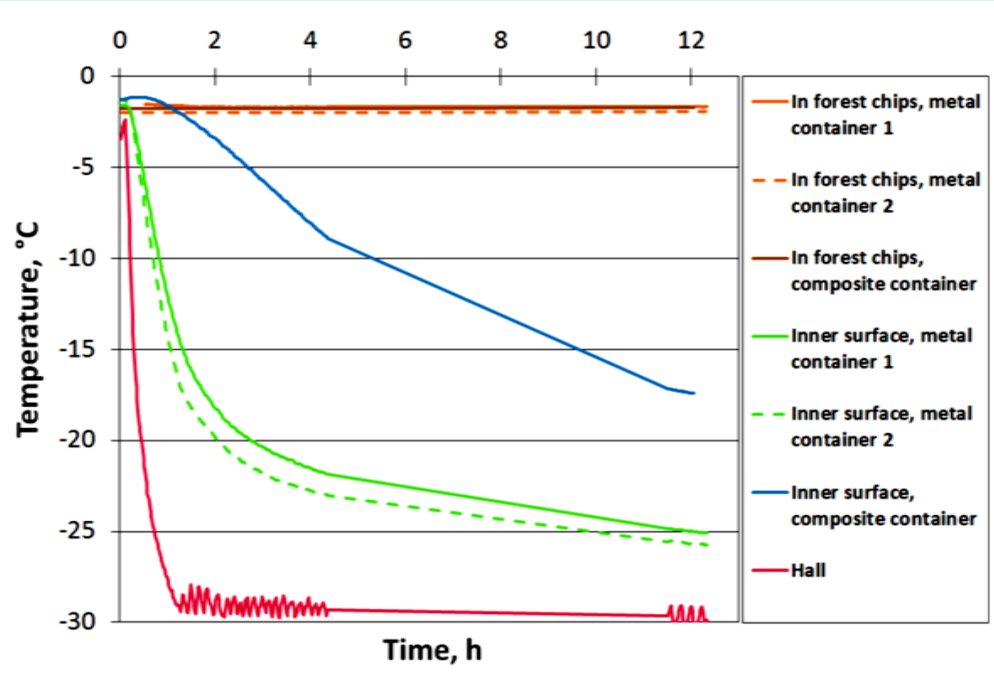

Figure 3. The 12-hour cold test of the containers.

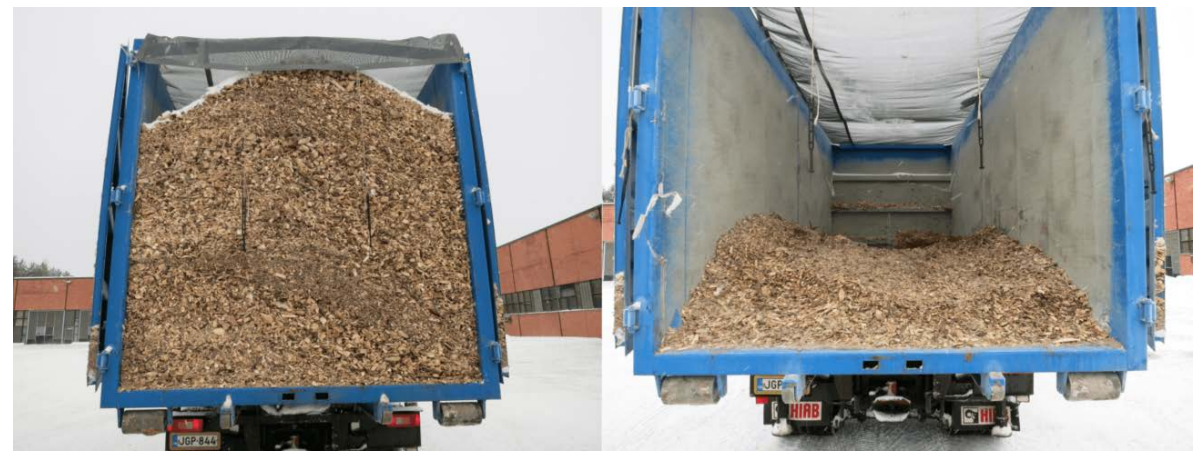

Figure 4. The metal container before unloading on the left and after on the right.

weight of the forest chips was $13.12 \mathrm{t}$ in the composite container. The composite container was transferred to the laboratory hall after the test of the metal containers. Figure 3 shows the results of the temperature measurements of the forest chips and inner surfaces of the composite container during the 12-hour cold test. There was a period of 7 hours when measurements were interrupted, from $4 \mathrm{~h}$ to $11 \mathrm{~h}$. The broken temperature curves are connected with a straight line in the graph.

During the test the temperature results in the composite container were similar to those of the metal containers. Only the temperature curve of the inner surface dropped less sharply and the end temperature $\left(-17^{\circ} \mathrm{C}\right)$ was higher than in the metal containers.

The chips were unloaded after the cold test. The chip content was frozen throughout in such a way that the chips were frozen to each other forming a $20 \mathrm{~cm}$ layer from the content surface. There was also some freezing below the entirely frozen layer, but these lower chips were not frozen to each other. Nevertheless, it was possible to empty the composite container of chips entirely. Figure 5 shows the situation of the composite container before and after unloading.

The unloaded heap of forest chips contained a lump of frozen chips similarly to the unloaded forest chips from the metal containers in the previous test. Due to the slippery inner surface, the unloaded chip mat was shorter in length than the unloaded chip mat from the metal containers.

\subsection{The 24-Hour Test with the Composite Container}

Due to the previous test results, it was decided to carry out a demanding cold test for the composite container with the same reloaded forest chips. This time, the composite container was kept at $-30^{\circ} \mathrm{C}$ for 24 hours. Figure 6 shows the results of the temperature measurements of forest chips and of the inner surfaces of the composite container during the 24-hour cold test. 


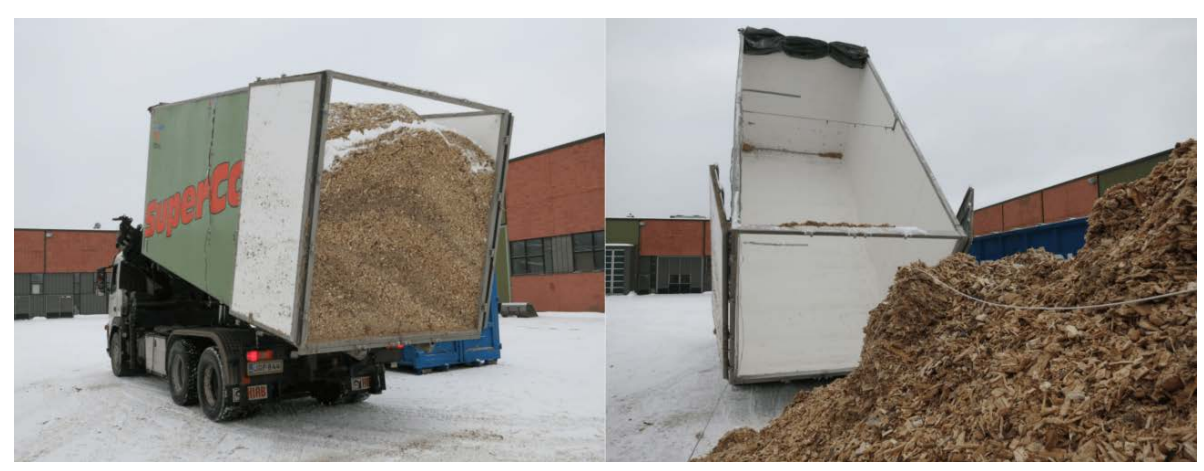

Figure 5. The composite container before unloading on the left and after on the right.

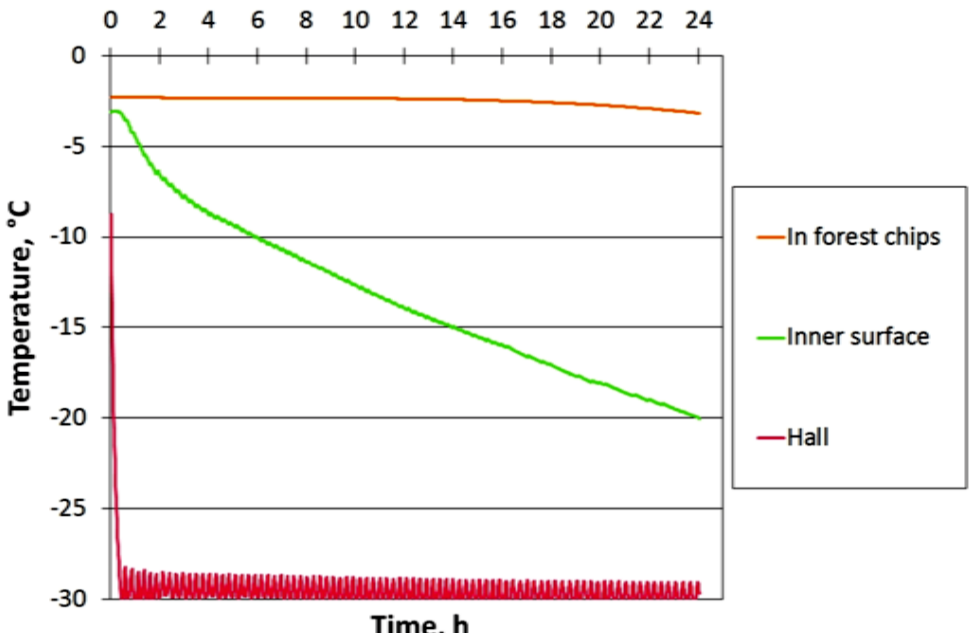

Time, h

Figure 6. The 24-hour cold test of the composite container.

The temperature results were similar to those of the previous cold test. The temperature decreased from $-2^{\circ} \mathrm{C}$ to $-3^{\circ} \mathrm{C}$ at a depth of $1 \mathrm{~m}$ in the heap of forest chips, and the end temperature of the inner surface was $-20^{\circ} \mathrm{C}$. The inner surface of composite container reached the temperature $-14^{\circ} \mathrm{C}$ in 12 hours, but in the previous test the temperature reached $-17^{\circ} \mathrm{C}$ in the same time. The difference can be explained by the time the chips were held in the container before testing. The period was shorter in the last cold test.

The forest chips were unloaded after the cold test. Once again, the forest chips had frozen to form a $20 \mathrm{~cm}$ layer from the content surface. Despite the layer of frozen chips, it was possible to empty the whole composite container of chips. Like earlier, the unloaded forest chip heap contained a lump of the frozen chips.

\section{Discussion and Conclusions}

This kind of experimental study applying cold tests with intermodal containers has never been done before. The study focused on the comparative cold tests wherein two metal containers and one composite container were loaded with forest chips. On the other hand, the results of cold tests can apply to alternative bulk materials that contain any moisture. All the containers were kept at $-30^{\circ} \mathrm{C}$ for 12 hours. In addition, the composite container was kept at the same temperature for 24 hours in an additional cold test. The containers were outside in temperatures below zero for two days before the tests started. The average moisture content of the forest chips was typical for the winter season, varying between $47 \%$ and $49 \%$.

The chip content was frozen throughout in such a way that the chips had frozen to each other to form a $20 \mathrm{~cm}$ layer from the content surface in all of the containers. There was also some freezing below the entirely frozen layer, but these lower chips were not frozen to each other. A layer of frozen chips with a thickness of approximately $50 \mathrm{~cm}-60 \mathrm{~cm}$ was stuck to the floors of the metal containers, which meant it was impossible to unload about $14 \%-17 \%$ of the total weight. The other metal container was treated with a special coolant, EC1, but that 
did not seem to affect either the freezing of the chips onto the inner surfaces or the unloading problems.

The composite container was emptied easily of the chips, both after the 12-hour and the 24-hour cold tests. Although the chip content had completely frozen in extreme cold temperatures, the chips were not stuck onto the inner surface of the composite container. Due to the slippery inner surface, the unloaded chip mat was shorter in length than the unloaded chip mat of the metal containers.

The intermodal containers are often used in challenging conditions in the Nordic countries. The use of antifreeze, like EC1, should be studied further in order to learn more about the freezing problems with metal containers in the future. Considering the further studies, the small-scale cold laboratory tests with a box less than 1 $\mathrm{m}^{3}$ would be more suitable for studying the advantage of the use of antifreeze with metal containers. In that case, the research would obtain more test repetitions and be therefore more reliable. In this study the repeatability of tests was an issue which was impossible to implement. The preparations for cold tests were difficult to realize, expensive and time-consuming. Also, it would have been necessary to use more temperature sensors and make cold tests in different temperatures and humidity.

According to the measurement results, the temperatures of the inner surfaces of the composite container decreased to $-15^{\circ} \mathrm{C}$ in about $10-14$ hours during the cold tests. In the metal containers the inner surfaces reached that same temperature in just 1 hour. The phenomenon is explained by the better thermal conductivity of the metal material. Thus, there is also the possibility that the chips are more likely to become stuck to the inner surface of the metal container than to the inner surface of the composite container.

Based on this study, long-lasting deliveries, lasting for example 2 - 3 days, are not suitable for moist bulk materials when metal containers are used in cold weather conditions. It was impossible to unload the metal containers of the chips perfectly after the cold test because there was a problem caused by chips freezing onto the floor. Major problems do not occur after deliveries lasting only a few hours, but chips start to freeze onto the inner surfaces when the delivery times are extended. Further improvements must be done for metal containers in order to make them more reliable when operating in extreme cold temperature conditions.

The problem with the freezing did not occur at any stage when the composite container was used during the cold tests. Therefore, it can be stated that the composite container is more cold-resistant than the metal containers. On the other hand, the chips were normally frozen into lumps, but the frozen chips were unloaded completely because of the slippery plastic composite material. The temperature of the chips within the heap was below zero, being about $-2^{\circ} \mathrm{C}$, in all cold tests. The composite container is suitable for the deliveries of bulk products in Nordic conditions, when there is a risk of freezing. The intermodal logistics of trucks and trains are promising for composite containers because of their frost-proof material, which prevents the bulk materials from freezing onto the inner surfaces. Such containers made of plastic composite have entered the intermodal container market. As a result of these tests their functionality has now been confirmed in unloading situations when operating in extreme cold temperature conditions.

\section{References}

[1] Torvelainen, J. (Ed.) (2014) Puun energiakäyttö 2013 [Energy Use of Wood in 2013]. Metsätilastotiedote [Forest Statistical Bulletin]. Official Statistics of Finland, Finnish Forest Research Institute. (In Finnish) http://www.metla.fi/metinfo/tilasto/julkaisut/mtt/2014/puupolttoaine2013.pdf

[2] Karttunen, K., Föhr, J., Ranta, T., Palojärvi, K. and Korpilahti, A. (2012) Puupolttoaineiden ja polttoturpeen kuljetuskalusto 2010 [Transportation Vehicles for Wood Fuels and Peat in 2010]. Metsätehon tuloskalvosarja. (In Finnish) http://www.metsateho.fi/files/metsateho/Tuloskalvosarja/Tuloskalvosarja_2012_02_Puupolttoaineiden_ja_polttoturpee n_kuljetuskalusto_ak_ym.pdf

[3] Strandström, M. (2013) Metsähakkeen tuotantoketjut Suomessa vuonna 2012 [Production Systems of Forest Chips in Finland, Year 2012]. Metsätehon tuloskalvosarja. (In Finnish)

http://www.metsateho.fi/files/metsateho/Tuloskalvosarja/Tuloskalvosarja_2013_04_Metsahakkeen_tuotantoketjut_201 2_ms.pdf

[4] Ministry of Employment and the Economy (2010) Suomen kansallinen toimintasuunnitelma uusiutuvista lähteistä peräisin olevan energian edistämisestä direktiivin 2009/28/EY mukaisesti [Finnish National Action Plan to Promote the Use of Energy from Renewable Sources in Accordance with the EU Directive 2009/28/EY]. Energy Department. http://www.tem.fi/files/29773/Suomen_kansallinen_toimintasuunnitelma.pdf

[5] Ranta, T. and Rinne, S. (2006) The Profitability of Transporting Uncomminuted Raw Materials in Finland. Biomass and Bioenergy, 30, 231-237. http://dx.doi.org/10.1016/j.biombioe.2005.11.012

[6] Ranta, T., Korpinen, O.-J., Jäppinen, E. and Karttunen, K. (2012) Forest Biomass Availability Analysis and Large-Scale 
Supply Options. Scientific Research, 2, 33-40. http://dx.doi.org/10.4236/ojf.2012.21005

[7] Enström, J. (2008) Efficient Handling of Wood Fuel within the Railway System. In: Suadicani, K. and Talbot, B., Eds., The Nordic-Baltic Conference on Forest Operations, Copenhagen, 23-25 September 2008, 53-55.

[8] Ranta, T., Föhr, J., Karttunen, K. and Knutas, A. (2014) Radio Frequency Identification and Composite Container Technology Demonstration for Transporting Logistics of Wood Biomass. Journal of Renewable and Sustainable Energy, 6, Article ID: 013115. http://dx.doi.org/10.1063/1.4862786

[9] Falkenberg, A. and Sökjer-Petersen, S. (2014) Transport Technology for Sustainable Intermodal Transports of Biofuel. MariTerm AB. http://www.mariterm.se/download/rapporter/biosun.pdf

[10] William, J.R. (1984) Cationic Polymers for Use in Freeze Protection of Coals and Minerals. US Patent: US4426409 A. http://www.google.com/patents/US4426409

[11] Enström, J. (2010) Greater Efficiency in Railway Transport of Forest Fuel. In: Thorsén, Å., Björheden, R. and Eliasson, L., Eds., Efficient Forest Fuel Supply Systems, Composite Report from a Four Year, R \& D Programme 2007-2010, Skogforsk, 80-83.

[12] Fibrocom Oy [Home Page of the Company]. Finland. http://www.fibrocom.com/index.php?page=containers\&container=eng

[13] Karttunen, K., Knutas, A., Föhr, J., Lättilä, L., Ikonen, J. and Ranta, T. (2012) Composite Container Logistics. Proceedings of the 20th European Biomass Conference and Exhibition, Milan, 18-22 June 2012, 107-115.

[14] EC1 Company AB [Home Page of the Company]. Sweden. http://www.ec1.se/index2.html 